\title{
Macrophage Growth Factors Introduced into the Kidney Initiate Renal Injury
}

\author{
Takero Naito,* Hitoshi Yokoyama,* Kathryn J. Moore,* \\ Glenn Dranoff, ${ }^{\dagger}$ Richard C. Mulligan, ${ }^{\dagger}$ and Vicki Rubin Kelley* \\ *Laboratory of Immunogenetics and Transplantation, Brigham $\delta$ \\ Women's Hospital and the Harvard Center for the Study of Kidney \\ Diseases, Harvard Medical School, Boston, Massachusetts, U.S.A. \\ tThe Whitehead Institute of Biomedical Research and the Department \\ of Biology, Massachusetts Institute of Technology, Cambridge, \\ Massachusetts, U.S.A.
}

\begin{abstract}
Background: CSF-1 expression precedes renal injury in autoimmune MRL-lpr mice and is responsible for macrophage $(\mathrm{M} \phi)$ proliferation and survival in the kidney. By comparison, $\mathrm{C} 3 \mathrm{H}-\mathrm{lpr}$ mice do not express CSF- $\mathrm{l}$ in the kidney, and despite the lpr mutation, kidneys remain normal. The purpose of this study was to test the capacity of local and systemic expression of $M \phi$ growth factor, CSF-1 to initiate renal injury in normal $(\mathrm{C} 3 \mathrm{H}-++$, MRL$++)$ and autoimmune (C3H-lpr, MRL-lpr) mice.

Materials and Methods: We designed a gene transfer system to deliver cytokines into the kidney by transducing renal tubular epithelial cells (TEC) using retroviral vectors expressing CSF-1 or another $M \phi$ growth factor, GM-CSF. We placed transduced syngeneic cytokineTEC under the renal capsule of normal and autoimmune prone mice prior to renal injury and evaluated renal pathology at 3, 7, 14, 28, and 90 days postimplant.
\end{abstract}

Results: CSF-1-TEC and GM-CSF-TEC, but not uninfected TEC, caused extensive local renal injury in strains with the lpr mutation. At 3-7 days the infiltrating cells were mainly $M \phi$, and by 28 days they were predominantly lymphocytes. By comparison, the kidneys of MRL- ++ and $\mathrm{C} 3 \mathrm{H}-++$ mice remained normal. Implanted genetically modified TEC caused a sustained increase of CSF-1 or GM-CSF in the circulation which did not modify the contralateral kidney.

Conclusions: Gene transfer of $\mathbf{M} \phi$ growth factors into the kidney initiates severe local renal injury in autoimmune prone mice with the lpr mutation, but does not compromise the kidney in nonautoimmune hosts. Of note, introduction of $\mathbf{M} \phi$ growth factors into the kidney of $\mathrm{C} 3 \mathrm{H}-\mathrm{lpr}$ mice which do not spontaneously develop renal injury incites renal damage. These studies offer a gene transfer approach to explore the impact of local and systemic cytokine production on renal injury.

\section{INTRODUCTION}

Macrophages $(\mathrm{M} \phi)$ can initiate and promote renal injury. They are ubiquitous in interstitial and glomerular lesions both in experimental and human kidney diseases (1). The mechanisms of $M \phi$ accumulation in the kidney that foster tissue injury are therefore central to renal tissue destruction. In MRL/MpJ-lpr/lpr (MRL-lpr) mice, which

Address correspondence and reprint requests to: Vicki Rubin Kelley, Transplantation \& Immunogenetics, Brigham $\delta$ Women's Hospital, 75 Francis Street, Boston, MA 02115 , U.S.A. mimic human systemic lupus erythematosus, $M \phi$ are particularly prominent in the kidney, and their presence precedes the loss of renal function (2). Renal damage is rapid $(50 \%$ mortality, 6 months of age) in these mice (3). The lpr mutation affects the gene encoding Fas, a molecule that mediates apoptosis (4). However, the lpr mutation alone is insufficient to induce renal injury since the kidneys remain normal in other background strains constructed to express $l p r$, such as $\mathrm{C} 3 \mathrm{H} / \mathrm{HeJ}-\mathrm{lpr} / \mathrm{lpr}(\mathrm{C} 3 \mathrm{H}-\mathrm{lpr})$ with the exception of the MRL-lpr strain. Therefore, the 
MRL background in which nonfatal glomerular and interstitial lesions gradually develop, is required for the $l p r$ mutation to accelerate the loss of renal function.

Colony stimulating factor-1 (CSF-1) and granulocyte-macrophage colony-stimulating factor (GM-CSF) are hematopoietic cytokines which attract $M \phi$ into tissues and are required for $M \phi$ growth and differentiation $(5,6)$. CSF-1 may be central to the initiation and promotion of renal injury in MRL-lpr mice: it is detectable in the circulation and kidneys of MRL-lpr mice well in advance of renal injury, but not in other strains with the lpr gene, MRL/MpJ-++ (MRL- ++$)$, or other normal strains (7). CSF-1 increases in proportion to the severity of the kidney disease (7), and it is produced primarily in glomeruli by mesangial cells which express a secreted and membrane form of the cytokine (8), and to a lesser degree in the interstitium (2). CSF-1 is required for the survival and proliferation of $M \phi$ propagated from MRL-lpr glomeruli (2). M $\phi$ are concentrated in areas within the kidney that express CSF-1 (2), and the loss of CSF-1 expression correlates with the disappearance of $M \phi$ and the reversal of renal lesions (9). These results indicate that CSF- 1 initiates and promotes autoimmune renal injury in MRL-lpr mice.

Strategies to introduce the CSF-1 gene into the kidney are limited since tissue-specific promoters that would tailor molecules for expression in selected cells only within the kidney have not been found. Gene transfer into the kidney could locally deliver a selected cytokine, but with previous systems gene transfer has been shortlived and variable (10-13). We designed a novel approach capable of continually delivering CSF-1 into the kidney. Using a retroviral gene transfer system, we transfected CSF-1 and another M $\phi$ growth factor, GM-CSF, into renal tubular epithelial cells (TEC), and then placed these genetically modified cells under the renal capsule of syngeneic strains. The result was stable expression of CSF-1 or GM-CSF in the kidney and circulation for sustained periods (weeks to months). We used this system to test the impact of sustained local and systemic delivery of $M \phi$ growth factors or other cytokines on renal injury.

\section{MATERIALS AND METHODS}

\section{Mice}

MRL-lpr, MRL-++, C3H/FeJ (C3H- ++$)$, and $\mathrm{C} 3 \mathrm{H}-\mathrm{lpr}$ mice were purchased from The Jackson
Laboratory (Bar Harbor, ME, U.S.A.) and maintained in our virus-free facility on standard laboratory chow. Female mice were used in all experiments to control for variation between sexes.

\section{Reagents}

Tissue culture media and supplements were purchased from Gibco/BRL Life Technologies (Grand Island, NY, U.S.A.) and chemicals were purchased from Sigma Chemical Co. (St. Louis, MO, U.S.A.). Polyclonal rabbit anti-murine CSF-1 antibody (Ab) was kindly provided by Dr. R. Shadduck (Montefiore Hospital, Pittsburgh, PA, U.S.A.). GM-CSF (clone MP1-31G6), CD4, CD8, and B220 monoclonal antibody $(\mathrm{mAb})$ were purchased from Pharmingen (San Diego, CA, U.S.A.). The hybridoma cell line F4/ 80, obtained from American Type Culture Collection (Rockville, MD, U.S.A.), secreted a mAb which specifically binds to $M \phi$.

\section{Isolation of Renal TEC}

We isolated TEC from MRL-lpr, MRL- ++ , and $\mathrm{C} 3 \mathrm{H}-++$ mice $1-2$ months of age as previously detailed (14). Briefly, kidneys were removed and renal cortices were minced, dispersed in collagenase solution, and then passed through a series of steel sieves $(250,150,75$, and $38 \mu \mathrm{m})$. Cells that passed through the final sieve were collected, washed in HBSS, and resuspended in modified $\mathrm{Kl}$ medium. The cells were incubated for $1 \mathrm{hr}$ at $37^{\circ} \mathrm{C}$ in culture dishes, and nonadherent cells were transferred to collagen (type IV)coated plates. TEC were cultured until they were confluent (Day 7-10 in MRL- ++ and $\mathrm{C} 3 \mathrm{H}-++$ TEC, and Day 10-14 in MRL-lpr). Finally, $1 \times$ $10^{6}$ TEC were plated on collagen-coated plates, and then infected with the recombinant retrovirus.

\section{Retrovirus-Mediated Cytokine Gene Transfer into Cultured TEC}

CRIP packaging cell lines that produced helperfree recombinant retroviruses carrying cytokine genes were generated as previously described (15-17). Briefly, DNA sequences encoding CSF-1 (bp 160-1871) and GM-CSF (bp 174-619) were subcloned into the Moloney murine leukemia virus (MoMuLV)-based MFG vector containing the LTR viral promoter and the $\psi$ sequence necessary for viral RNA packaging. The MFG vector carrying a cytokine gene was then introduced into a mammalian packaging cell line (CRIP) 
which contains integrated proviral sequences necessary for encapsulation of the recombinant viral RNA. The resulting virus-producing cell line produces recombinant retroviruses which transfer the recombinant viral genome containing the selected cytokine gene into a suitable host cell. Producer cells were grown to subconfluence $(5 \times$ $10^{6}$ cells on a $10-\mathrm{cm}$ culture dish) in Dulbecco's modified Eagle's medium (DMEM) complete medium containing $10 \%$ calf serum, replenished with $10 \mathrm{ml}$ of fresh medium and incubated for 18 $\mathrm{hr}$. The virus-containing cell culture supernatant was harvested, filtered through a $0.45-\mu \mathrm{m}$ membrane, and viral stocks were applied to TEC cultures $\left(1 \times 10^{6}\right.$ cells on a $10-\mathrm{cm}$ culture dish) in the presence of $8 \mu \mathrm{g} / \mathrm{ml}$ polybrene for $18 \mathrm{hr}$. Following retroviral infection, TEC were replenished with $\mathrm{Kl}$ medium, grown to confluence (5-6 day), and culture supernatants were collected to verify cytokine secretion. The bacterial $\beta$-galactosidase ( $\beta$-gal) gene (LacZ) was introduced into TEC coincidentally with CSF-1-encoding sequences ("cotransfection") to track genetically modified TEC.

\section{Detection of CSF-1, GM-CSF, and $\beta$-gal in Genetically Modified TEC}

CSF-1, GM-CSF production by genetically modified TEC was determined in cultured cells by immunohistochemical analysis. We cultured TEC for $48 \mathrm{hr}$ on tissue culture chamber slides, fixed these cells with $95 \%$ ethanol, and then stained for the presence of CSF-1, GM-CSF using the immunoperoxidase technique. We blocked endogenous peroxidase activity with $0.6 \%$ hydrogen peroxide $\left(\mathrm{H}_{2} \mathrm{O}_{2}\right)$ and $0.2 \%$ sodium azide for $10 \mathrm{~min}$, washed the TEC with $0.01 \mathrm{M}$ Trisbuffered saline (TBS) containing $0.1 \%$ bovine serum albumin (BSA), and blocked endogenous avidin and biotin using an Avidin/Biotin blocking kit (Vector Laboratories, Burlingame, CA, U.S.A.). The TEC were then incubated with biotinylated rat anti-murine GM-CSF Ab $(5 \mu \mathrm{g} / \mathrm{ml})$ in a humidified chamber for $2 \mathrm{hr}$ at room temperature, washed, and then exposed to avidinperoxidase complex using the Vectastain $A B C$ Elite Kit (Vector Laboratories) to detect GM-CSF. For indirect detection of CSF-1, rabbit antiCSF-1 sera incubation was followed with biotinylated goat anti-rabbit IgG for $1 \mathrm{hr}$ at room temperature, and then exposed to avidin-peroxidase complex. TEC were then exposed to 3-3'diamino-benzidine $(0.5 \mathrm{mg} / \mathrm{ml}$ in TBS containing $0.02 \% \mathrm{H}_{2} \mathrm{O}_{2}$ ) for a chromogenic reaction and counterstained with methyl green/alcian blue. Specificity controls included replacement of primary $\mathrm{Ab}$ with normal rat IgG or rabbit sera. To verify transfer of the LacZ gene in coinfected TEC, $\beta$-gal expression was evaluated in cultured TEC by treating cells with 5 -bromo-4-chloro-3indolyl- $\beta$-D-galactoside (X-gal) (18). In brief, TEC cultures were fixed with $1 \%$ glutaraldehyde for $15 \mathrm{~min}$ at $37^{\circ} \mathrm{C}$ and incubated in a X-gal solution (1 $\mathrm{mM} \mathrm{MgCl}{ }_{2}$ in phosphate-buffered saline [PBS], $5 \mathrm{mM}$ potassium ferriferrocyanide, $1 \mathrm{mg} / \mathrm{ml} \mathrm{X}$-gal in $\mathrm{N}, \mathrm{N}$-dimethylformamide, $\mathrm{pH} 7.5$ ) at $37^{\circ} \mathrm{C}$ for $1 \mathrm{hr}$. Cells with $\beta$-gal activity were identified by the presence of blue-green color in the cytoplasm.

\section{Measurement of Secreted CSF-1 and GM-CSF}

Biologically active CSF-1 and GM-CSF in TEC supernatants and sera samples were measured by colony-stimulating assay (CSA) as previously described (19). Briefly, bone marrow cells were extracted from the tibias of $\mathrm{C} 3 \mathrm{H}-++$ mice, and 1 $\times 10^{5}$ bone marrow cells were added to supernatant $(100 \mu \mathrm{l})$ or test serum $(30 \mu \mathrm{l})$, and then plated in $1 \mathrm{ml} 0.3 \%$ Noble agar (Difco, Detroit, MI, U.S.A.) in McCoy's 5A medium supplemented with $15 \%$ fetal calf serum (FCS), $50 \mathrm{mM}$ 2-ME, $10 \mathrm{U} / \mathrm{ml}$ penicillin, and $100 \mu \mathrm{g} / \mathrm{ml}$ streptomycin in $35-\mathrm{mm}$ tissue culture plates. Cultures were incubated at $37^{\circ} \mathrm{C}$ in a humidified $5 \% \mathrm{CO}_{2}$ atmosphere and colonies were counted on Day 10. The results were reported as CFU per $10^{5}$ bone marrow cells. To verify the specificity of CSF- 1 and GM-CSF induced colonies, test sera or culture supernatants were preincubated with 30 $\mu \mathrm{l}$ of polyclonal rabbit anti-murine CSF- $1 \mathrm{Ab}$ or rat anti-murine $\mathrm{GM}-\mathrm{CSF} \mathrm{mAb}$ for $30 \mathrm{~min}$ at room temperature prior to the assay. Cytokine levels are reported as the amount produced by $5 \times 10^{5} \mathrm{TEC} / \mathrm{ml}$.

\section{Placing TEC under the Renal Capsule}

We implanted uninfected or cytokine-producing TEC directly under the renal capsule of recipient mice $4,6-8,10-12$, or 20 weeks of age. We anesthetized mice by i.p. injection of sodium pentobarbital ( $1 \mathrm{mg} / \mathrm{mouse}$ ) and ether inhalation, and then exposed the left kidney through a left flank incision. Under a dissecting microscope, a cell suspension of either $0.5,1$, or $5 \times 10^{6}$ TEC in $50 \mu \mathrm{l}$ of HBSS was injected into the subcapsular space, and the peritoneum and skin were 
closed. The maximal number of TEC which the subcapsular space could accommodate was $5 \times$ $10^{6}$ TEC. The viability of TEC immediately before implantation (Ix) was $>90 \%$ by trypan blue staining. We implanted TEC derived from $\mathrm{C} 3 \mathrm{H}-++$ and MRL-lpr mice under the renal capsule of syngeneic strain with or without the lpr mutation. To exclude the possibility that the $l p r$ mutation altered the TEC, we implanted C3H-lpr-derived TEC into C3H-++ recipients, and MRL-++ TEC into MRL$l p r$ recipients. Recipient mice were bled before Ix and 7,14 , and 28 days post-Ix to evaluate cytokine levels in the circulation.

\section{Histological Examinations}

We removed the TEC-implanted (left) kidney, as well as the contralateral (right) kidney at 3, 7, $14,28,56$, and 90 days post-Ix. The kidneys were halved and fixed in $10 \%$ phosphate-buffered formalin for paraffin-embedded sections or snapfrozen in OCT compound (Miles, Naperville, IL, U.S.A.). Paraffin-embedded tissue sections were stained by the hematoxylin and eosin method and evaluated by light microscopy. We assessed the accumulation of cells in the subcapsular site, and in the renal cortex by counting the maximum number of cell layers in the area with the most extensive pathology. Using paraffin-embedded sections we detected $M \phi$ and lymphocytes by the immunoperoxidase method using F4/80 and Ab to CD4, CD8, and B220 determinants (2). Specificity controls included the replacement of primary Ab with normal rat IgG. Tissue $\beta$-gal activity was evaluated on frozen sections by incubation with X-gal solution using the same method for TEC cultures described above, with an additional incubation with the $\mathrm{X}$-gal solution $(1 \mathrm{hr})(12,18)$.

\section{RESULTS}

\section{TEC Transfected with CSF-1 and GM-CSF Encoding Genes Constitutively Produce and Secrete High Levels of These Cytokines}

TEC will be identified by naming the introduced gene and the cell type (e.g., CSF-1-TEC). CSF-1TEC derived from $\mathrm{C} 3 \mathrm{H}-++$ mice secreted high levels of CSF-1 into the supernatant when tested 1 week after retroviral infection (Table 1). Similarly, GM-CSF-TEC secreted substantial amounts of GM-CSF into the supernatants after 1 week of culture. CSF-1 and GM-CSF were undetectable in
TABLE 1. Genetically modified TEC constitutively secrete CSF-1 and GM-CSF, and retain the ability to secrete each cytokine for at least 4 months

\begin{tabular}{lccc}
\hline $\begin{array}{l}\text { Culture } \\
\text { Period }\end{array}$ & $\begin{array}{c}\text { CSF-1 } \\
\text { (CFU) }\end{array}$ & $\begin{array}{c}\text { GM-CSF } \\
\text { (CFU) }\end{array}$ & $\begin{array}{c}\text { Uninf. } \\
\text { (CFU) }\end{array}$ \\
\hline 1 week & 56 & 41 & 0 \\
1 month & 66 & 46 & 4 \\
4 months & 51 & 50 & 3 \\
6 months & 73 & - & - \\
8 months & 42 & - & - \\
10 months & 23 & - & - \\
\hline
\end{tabular}

TEC were derived from $\mathrm{C} 3 \mathrm{H}-++$ mice. CSF-1 and GM-CSF were measured by colony-stimulating assay as CFU per $10^{5}$ bone marrow cells. Positive standard for the assay is MRL$l p r$ sera at 6 months of age, $53 \pm 4$ CFU. Culture period, period after retroviral infection; Uninf., retroviral uninfected TEC. Culture supernatants $\left(1 \mathrm{ml} / 5 \times 10^{5} \mathrm{TEC}\right)$ were collected 6 days after passage. All values are means of duplicate samples.

supernatants from uninfected TEC. The genetically modified TEC retained the ability to secrete each selected cytokine for several mos (CSF-1 $>6$ months, GM-CSF $>4$ months; Table 1). To determine if the background strain of TEC affected the capacity to produce and secrete each cytokine, we evaluated TEC cultures of three different strains, $\mathrm{C} 3 \mathrm{H}-++$, MRL- ++ , and MRL-lpr. Genetically modified TEC from each strain secreted similar amounts of CSF-1 and GM-CSF (Table 2). CSF-1 was expressed in the cytoplasm in a diffuse, granular pattern in $>90 \%$ of CSF1-TEC (Fig. 1A), but not in TEC which were not retroviral infected (Fig. 1B). GM-CSF was visible in $>90 \%$ of TEC infected with retroviruses encoding GM-CSF, but not in uninfected TEC (Fig. 1C).

\section{Genetically Modified TEC (Cytokine-TEC) Placed under the Renal Capsule Cause an Increase of the Cytokine in the Circulation}

We evaluated levels of each cytokine in the circulation 7,14 , and 28 days post-Ix in mice with and without the $l p r$ mutation. In $\mathrm{C} 3 \mathrm{H}-++$ and C3H-lpr recipients implanted with $1 \times 10^{6}$ syngeneic CSF-1-TEC circulating CSF-1 levels increased from undetectable to $12 \pm 6 \mathrm{CFU}$, and $14 \pm 3$ CFU after $28 \mathrm{~d}$ (Table 3). In one month old MRL-lpr recipients of CSF-1-TEC or GM-CSFTEC, circulating levels of CSF-1 or GM-CSF were 
TABLE 2. Constitutive secretion of CSF- 1 and GM-CSF by genetically modified TEC is similar in several strains

\begin{tabular}{lccc}
\hline $\begin{array}{l}\text { TEC } \\
\text { (Strain) }\end{array}$ & $\begin{array}{l}\text { CSF-1 } \\
\text { (CFU) }\end{array}$ & $\begin{array}{c}\text { GM-CSF } \\
\text { (CFU) }\end{array}$ & $\begin{array}{c}\text { Uninf. } \\
\text { (CFU) }\end{array}$ \\
\hline C3H-++ & 66 & 46 & 4 \\
MRL-++ & 63 & 30 & 4 \\
MRL-lpr & 68 & 39 & 3 \\
\hline
\end{tabular}

Culture supernatants $\left(1 \mathrm{ml} / 5 \times 10^{5} \mathrm{TEC}\right)$ were collected 1 month after retroviral infection. CSF-1 and GM-CSF were measured by colony stimulating assay as CFU per $10^{5}$ bone marrow cells. Positive standard for the assay is MRL-lpr sera at 6 months of age, $53 \pm 4 \mathrm{CFU}$. All values are means of duplicate samples. Uninf., retroviral uninfected TEC.
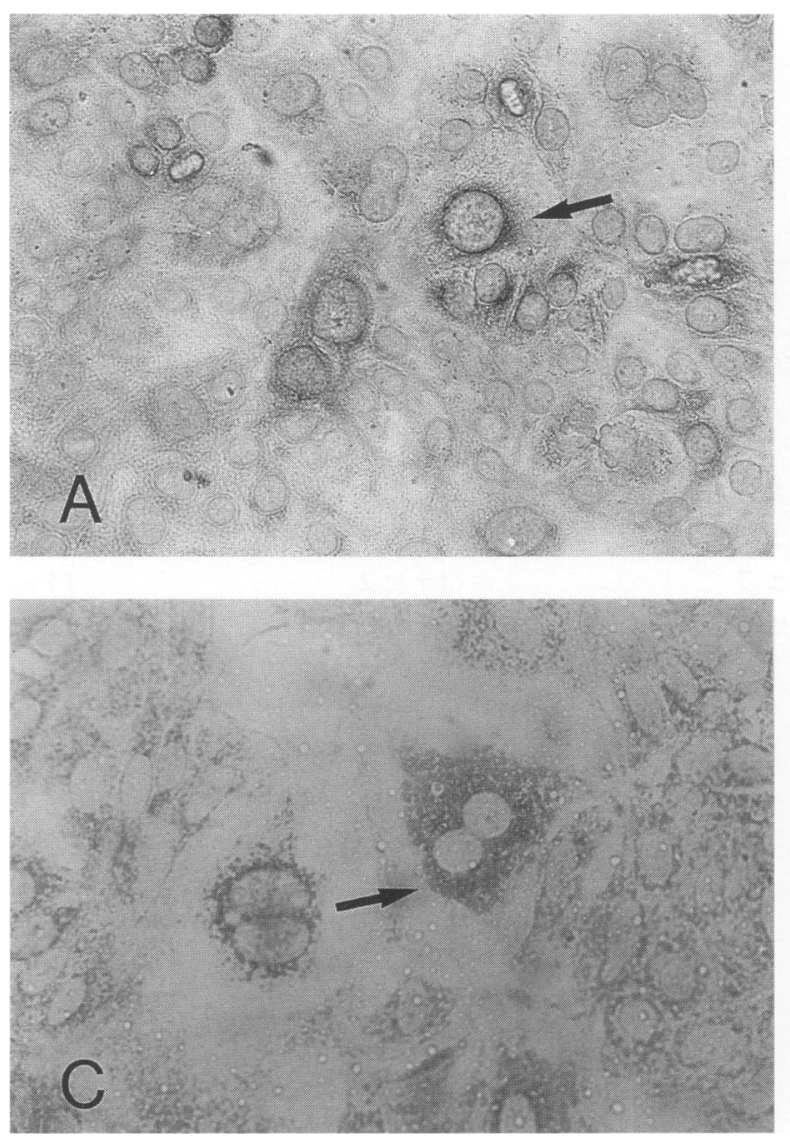

$4 \pm 0$ and $0 \pm 0 \mathrm{CFU}$, and increased to $25 \pm 5$ and $15 \pm 10 \mathrm{CFU}$, respectively, 28 days post-Ix. Implants of unmodified TEC did not increase CSF-1 or GM-CSF in the circulation (Table 3).

\section{CSF-1-TEC and GM-CSF-TEC Implants Induce Intrarenal Accumulation of Cells in Recipient Mice with the lpr Mutation, but Not in Normal Mice}

TEC producing either CSF-1 or GM-CSF caused a substantially greater accumulation of cells in the implant site than uninfected TEC in $\mathrm{C} 3 \mathrm{H}-\mathrm{lpr}$ and MRL-lpr (Table 4A and Figs. 2 and 3). In contrast, neither of the $M \phi$ growth factors induced an accumulation of cells in the kidneys of mice without the $l p r$ mutation $(\mathrm{C} 3 \mathrm{H}-++$ and MRL++ ). GM-CSF-TEC and CSF-1-TEC caused more cells to accumulate in the subcapsular site in
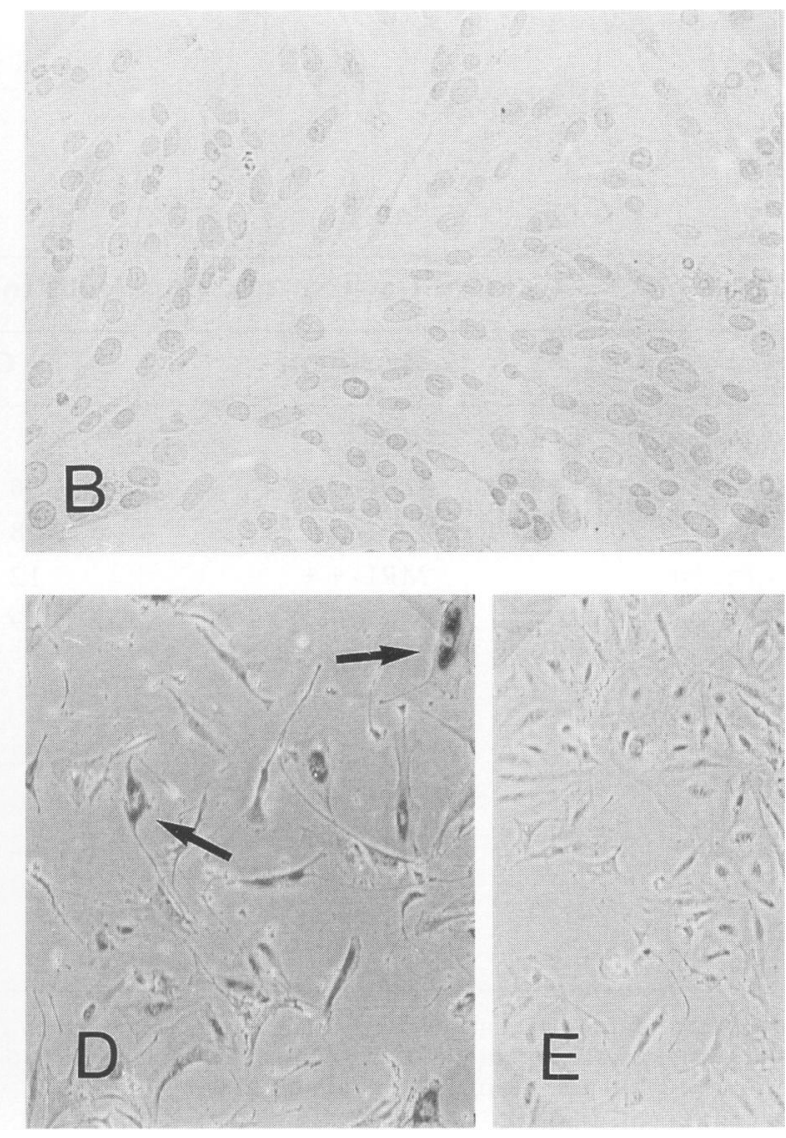

FIG. 1. Cytokine expression of by CSF-1-TEC and GM-CSF-TEC is efficient and constitutive

Cultured CSF-1-TEC (A, arrow), but not uninfected TEC (B), constitutively expressed CSF-1 in the cytoplasm. Similarly, GM-CSF-TEC (C, arrow) expressed GM-CSF. $\beta$-gal activity was identified in $\beta$-gal-CSF-1-TEC (D, arrows), but not in uninfected TEC (E). Cultured TEC were derived from $\mathrm{C} 3 \mathrm{H}-++$ mice. (Magnification: $\mathrm{A}, 750 \times$; $\mathrm{B}, 500 \times ; \mathrm{C}, 1000 \times ; \mathrm{D}$ and $\mathrm{E}, 500 \times$.) 
TABLE 3. Retrovirally infected CSF-1-TEC and GM-CSF-TEC implanted under renal capsule increase cytokine in the circulation

\begin{tabular}{llcccc}
\hline & & \multicolumn{3}{c}{ Serum CSF-1, GM-CSF (CFU) } \\
\cline { 3 - 5 } $\begin{array}{l}\text { Recipient } \\
\text { (Strain) }\end{array}$ & & & \multicolumn{3}{c}{ Post-Ix } \\
\cline { 3 - 5 } & TEC & Pre-Ix & $\mathbf{7}$ days & 14 days & $\mathbf{2 8}$ days \\
\hline C3H-++ & CSF-1 & $0 \pm 0$ & - & - & $12 \pm 6^{a}(0)^{b}$ \\
& Uninf. & $0 \pm 0$ & $0 \pm 0$ & $0 \pm 0$ & $0 \pm 0$ \\
C3H-lpr & CSF-1 & $0 \pm 0$ & $7 \pm 2^{a}$ & - & $14 \pm 3^{a}(0)$ \\
MRL-lpr & CSF-1 & $4 \pm 0(1)$ & $10 \pm 3^{a}$ & $13 \pm 1^{a}$ & $25 \pm 5^{a}(0)$ \\
& GM-CSF & $0 \pm 0(0)$ & $13 \pm 5^{a}(1)$ & $8 \pm 4^{a}(1)$ & $15 \pm 10^{a}(3)$ \\
& Uninf. & $4 \pm 0(1)$ & $3 \pm 1$ & $2 \pm 2$ & $5 \pm 2(0)$
\end{tabular}

Recipient mice are 4-8 weeks of age. $n=3-4$ in each group. Number of implanted cells: $1 \times 10^{6} / \mathrm{mouse}$. CSF-1 and GM-CSF were measured by colony stimulating assay as CFU per $10^{5}$ bone marrow cells. Positive standard for the assay was MRL-lpr sera at 6 months of age, $53 \pm 4 \mathrm{CFU}$. Ix, implantation; Uninf.; retroviral uninfected TEC.

$a_{p}<0.05$ versus pre-Ix value.

${ }^{b}$ Neutralized by anti-CSF-1 or GM-CSF Ab.

TABLE 4. CSF-1-TEC or GM-CSF-TEC cause cells to accumulate in mice with the lpr mutation

\begin{tabular}{|c|c|c|c|c|}
\hline TEC & Recipient & CSF-1 & GM-CSF & Uninf. \\
\hline \multicolumn{5}{|c|}{ A. Subcapsular } \\
\hline \multirow[t]{2}{*}{$\mathrm{C} 3 \mathrm{H}-++$} & $\mathrm{C} 3 \mathrm{H}-++$ & $16 \pm 3$ & $16 \pm 4$ & $12 \pm 1$ \\
\hline & $\mathrm{C} 3 \mathrm{H}-l p r$ & $28 \pm 7^{b, c}$ & $33 \pm 3^{b, c}$ & $12 \pm 1$ \\
\hline \multirow[t]{2}{*}{ MRL-lpr } & MRL- ++ & $12 \pm 3$ & $15 \pm 2$ & $14 \pm 1$ \\
\hline & MRL-lpr & $39 \pm 7^{b, d, e}$ & $57 \pm 7^{b, d, e}$ & $12 \pm 2$ \\
\hline MRL-++ & MRL-lpr & - & $47 \pm 8^{b, e}$ & $14 \pm 2$ \\
\hline \multicolumn{5}{|l|}{ B. Intrarenal ${ }^{a}$} \\
\hline \multirow[t]{2}{*}{$\mathrm{C} 3 \mathrm{H}-++$} & $\mathrm{C} 3 \mathrm{H}-++$ & $2 \pm 1$ & $3 \pm 1$ & $2 \pm 1$ \\
\hline & $\mathrm{C} 3 \mathrm{H}-\mathrm{lpr}$ & $16 \pm 3^{b, c}$ & $32 \pm 2^{b, c, f}$ & $2 \pm 1$ \\
\hline \multirow[t]{2}{*}{ MRL-lpr } & MRL- ++ & $2 \pm 1$ & $3 \pm 1$ & $2 \pm 1$ \\
\hline & MRL-lpr & $19 \pm 4^{b, d}$ & $49 \pm 6^{b, d, f}$ & $2 \pm 1$ \\
\hline MRL- + + & MRL-lpr & - & $42 \pm 7^{b}$ & $2 \pm 1$ \\
\hline
\end{tabular}

${ }^{a}$ Subcapsular and intrarenal cell accumulation was evaluated by counting the numbers of cell layers in an area with the greatest lesion. Histological evaluation; 28 days post-Ix. Recipient mice: $6-8$ weeks of age. $n=3-5$ in each group. Number of implanted cells: $5 \times 10^{6} /$ mouse. Uninf., retroviral uninfected TEC.

${ }^{b} p<0.05$ versus Uninf.

$c_{p}<0.05$ versus $\mathrm{C} 3 \mathrm{H}-++$ recipient.

${ }^{d} p<0.05$ versus MRL- ++ recipient.

${ }^{e} p<0.05$ versus $\mathrm{C} 3 \mathrm{H}-\mathrm{lpr}$ recipient.

$f_{p}<0.05$ versus CSF-1. 

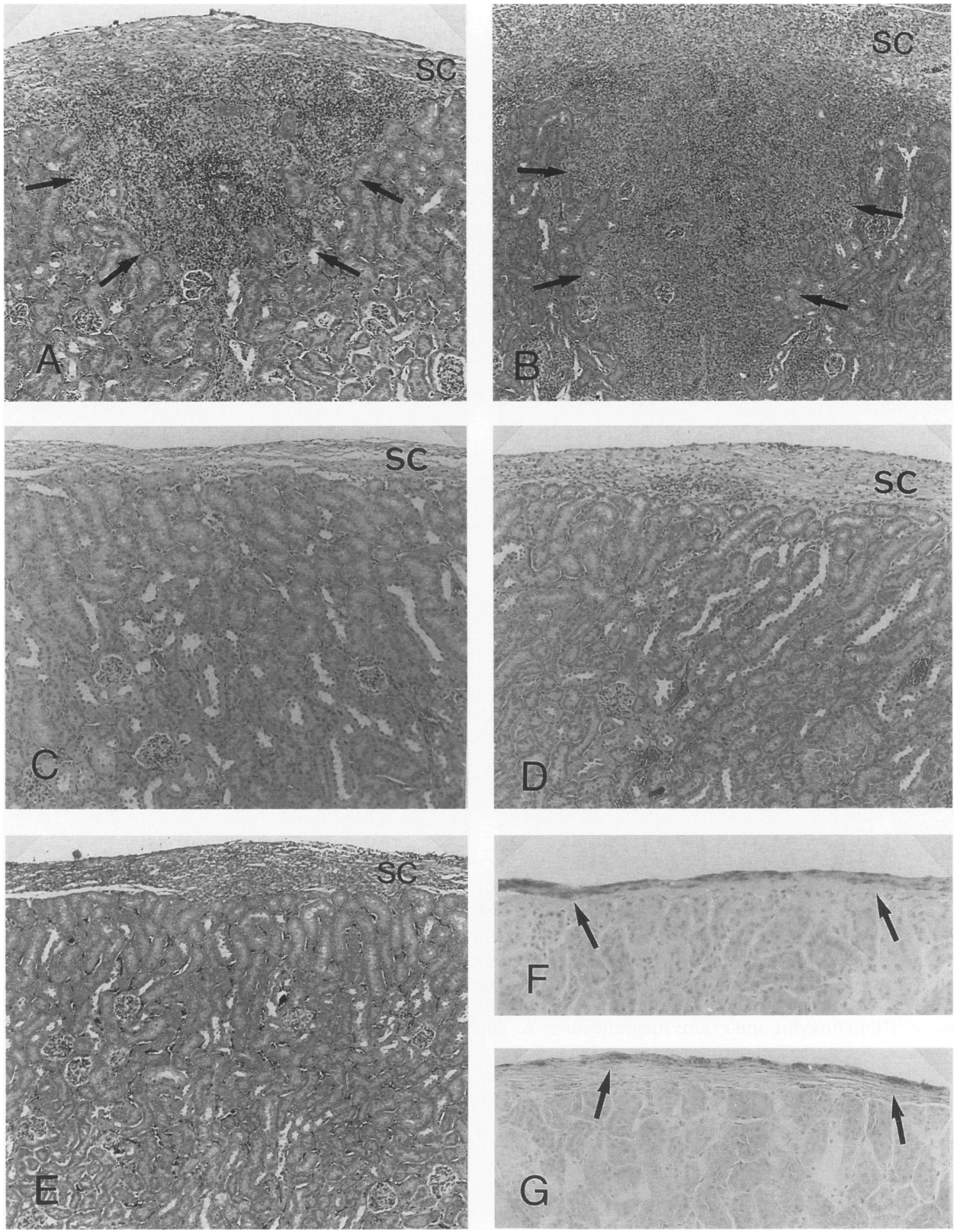

FIG. 2. Subcapsular implantation of CSF-1-TEC and GM-CSF-TEC into MRL strain induces renal injury in mice with the $l p r$ mutation

Implantation of CSF-1-TEC under the renal capsule caused a wedge-shaped intrarenal infiltrative lesion (A, arrows), and GM-CSF-TEC induced severe lesion extending through the cortex into the medulla (B, arrows) in MRL-lpr recipients. By comparison, neither CSF-1 (C) nor GM-CSF (D) induced any intrarenal lesion and only induced a modest accumulation of cells in the subcapsular sites in MRL- ++ mice. Similarly, uninfected TEC implanted into MRL-lpr recipients (E) did not cause intrarenal lesion. $\beta$-gal-CSF-1-TEC implanted into MRL-lpr mice stained for the presence of $\beta$-gal are confined to the renal subcapsule 3 days post-Ix ( $F$, arrows), and 14 days post-Ix (G, arrows). sc, subcapsular space. (Hematoxylin and eosin; magnification: 200×.) 

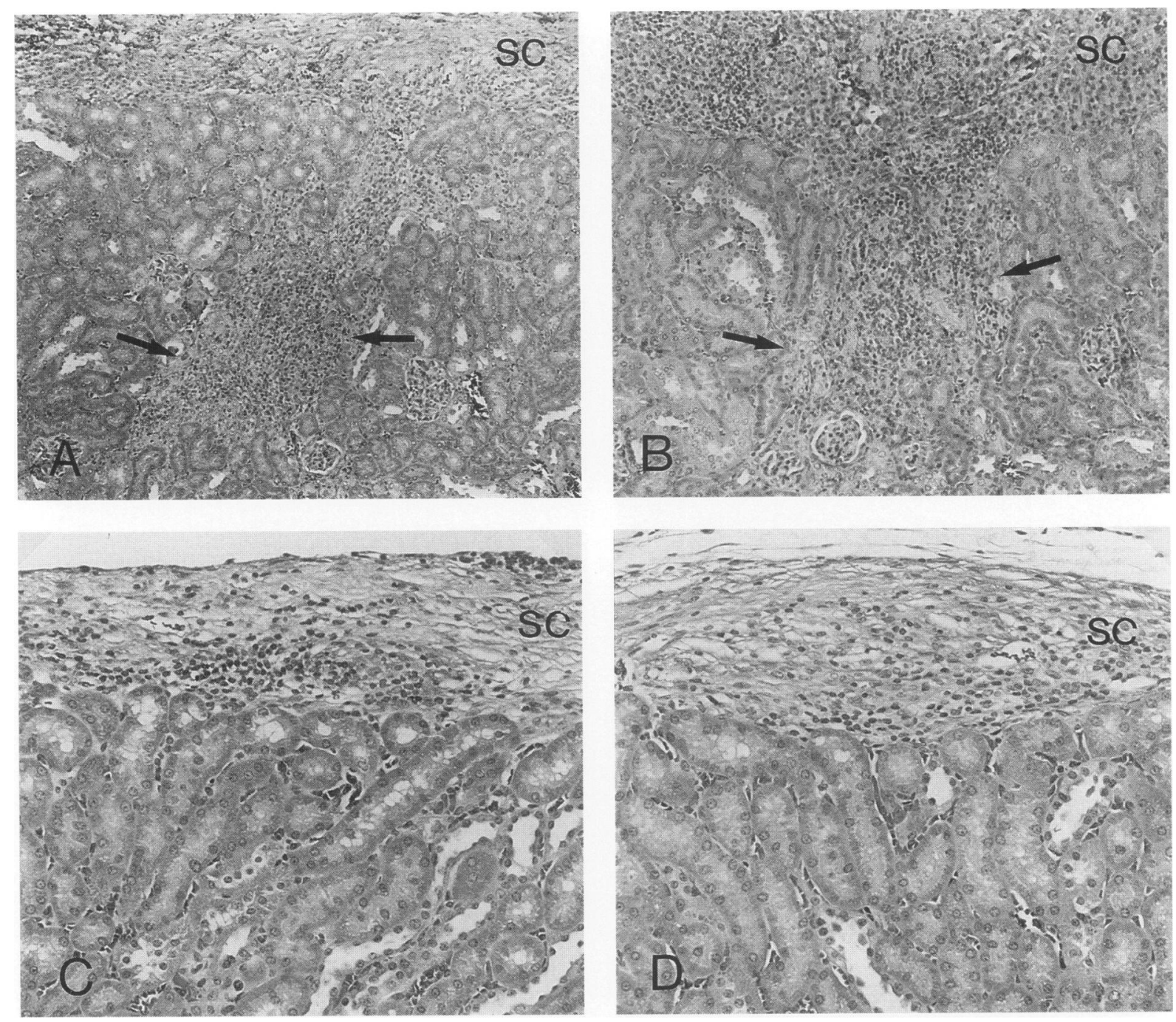

FIG. 3. Implantation of CSF-1-TEC and GM-CSF-TEC into the C3H strain induces renal injury in mice with the lpr mutation

Note the accumulation of cells in the renal cortex (arrows) extending from the subcapsular site in $\mathrm{C} 3 \mathrm{H}-\mathrm{lpr}$ mice that received CSF-1-TEC (A) and GM-CSF-TEC (B). By comparison, C3H-++ implanted with CSF-1-TEC (C) and GM-CSF-TEC (D) did not induce any notable accumulation of cells in the renal cortex. 28 days post-Ix. sc, subcapsular space. (Hematoxylin and eosin; magnification: A, 200×; B, 300×; C and D, 500×.)

MRL-lpr recipients than in $\mathrm{C} 3 \mathrm{H}-\mathrm{lpr}$ recipients. CSF-1-TEC and GM-CSF-TEC caused massive intrarenal cell accumulations in C3H-lpr and MRLlpr, but not in $\mathrm{C} 3 \mathrm{H}-++$ and $\mathrm{MRL}-++$ recipients (Table 4B and Figs. 2 and 3). GM-CSF-TEC from MRL- + + and MRL-lpr mice caused a similar cell accumulation in the subcapsular site and within the kidney of MRL-lpr mice, indicating that the TEC did not need to be derived from mice with the $l p r$ mutation to induce renal injury (Table 4).
We placed $0.5 \times 10^{6}, 1 \times 10^{6}$, or $5 \times 10^{6}$ CSF-1-TEC or GM-CSF-TEC under the renal capsule of a MRL-lpr kidney, and compared the subcapsular and intrarenal lesions in each group. Subcapsular and intrarenal lesions induced by $1 \times 10^{6}$ CSF-1-TEC and GM-CSF-TEC were greater than those induced by $0.5 \times 10^{6}$ TEC $(p<0.05)$, but equivalent to those induced by $5 \times$ $10^{6}$ TEC (Table 5). Based on these data, we implanted $1 \times 10^{6}$ TEC in succeeding experiments. 
TABLE 5. Implantation of $1 \times 10^{6} \mathrm{CSF}-1-\mathrm{TEC}$ and GM-CSF-TEC is sufficient to induce maximal subcapsular and intrarenal lesions

\begin{tabular}{ccccc}
\hline & \multicolumn{2}{c}{ CSF-1 } & \multicolumn{2}{c}{ GM-CSF } \\
\cline { 2 - 5 } Cell Number & Subcapsular $^{a}$ & Intrarenal $^{a}$ & & Subcapsular $^{a}$ \\
\hline $5 \times 10^{6}$ & $37 \pm 6^{b}$ & $17 \pm 4^{b}$ & $59 \pm 8^{b}$ & $49 \pm 2^{b}$ \\
$1 \times 10^{6}$ & $36 \pm 5^{b}$ & $20 \pm 4^{b}$ & $65 \pm 10^{b}$ & $45 \pm 4^{b}$ \\
$0.5 \times 10^{6}$ & $25 \pm 1$ & $9 \pm 3$ & $22 \pm 2$ & $21 \pm 3$
\end{tabular}

${ }^{a}$ Subcapsular and intrarenal cell infiltration was evaluated by counting the numbers of cell layers in an area with the greatest lesion. Histological examination: 28 days post-Ix. Recipient are MRL-lpr mice, 7 weeks of age. $n=3$ in each group.

${ }^{b} p<0.05$ versus $0.5 \times 10^{6}$.

\section{GM-CSF-TEC Incites a More Rapid Cell Accumulation Than CSF-1-TEC in MRL-lpr Recipients, and Renal Lesions Induced by GM-CSF-TEC and CSF-1-TEC Are Persistent}

We examined MRL-lpr kidneys that were implanted with CSF-1-TEC or GM-CSF-TEC, 3, 7, $14,28,56$, and 90 days post-Ix. Compared with CSF-1-TEC, GM-CSF-TEC in MRL-lpr kidneys induced a more rapid accumulation of cells under the renal capsule and within the kidney (Table 6). The intrarenal accumulation of cells in- duced by GM-CSF was approximately 3-fold higher, compared with CSF-1, at 3, 7, and 28 days (Table 6 and Fig. 4). The total number of cells accumulating (subcapsular + intrarenal) in response to GM-CSF-TEC and CSF-1-TEC at 90 days were $143 \pm 35,115 \pm 32$ cell layers, respectively. The response to GM-CSF-TEC peaked by 28 days and remained elevated until 90 days; the response to CSF-1-TEC increased 2 -fold from 28 days ( $64 \pm 8$ cell layers), until 56 days (123 \pm 28 cell layers) and 90 days ( $115 \pm 32$ cell layers) post-Ix. It is important to note that uninfected

TABLE 6. GM-CSF-TEC implanted into MRL-lpr recipients induce a more rapid cell infiltration than CSF-1-TEC

\begin{tabular}{|c|c|c|c|c|}
\hline \multirow[b]{2}{*}{ TEC } & \multicolumn{4}{|c|}{ Post-Ix } \\
\hline & 3 Days & 7 Days & 14 Days & 28 Days \\
\hline \multicolumn{5}{|c|}{ A. Subcapsular } \\
\hline CSF-1 & $17 \pm 2$ & $27 \pm 5^{b}$ & $32 \pm 5^{b}$ & $29 \pm 3^{b}$ \\
\hline GM-CSF & $19 \pm 3$ & $44 \pm 8^{b}$ & $70 \pm 14^{b, c}$ & $68 \pm 13^{b, c}$ \\
\hline Uninf. & $12 \pm 2$ & $13 \pm 1$ & $14 \pm 2$ & $14 \pm 2$ \\
\hline \multicolumn{5}{|c|}{ B. Intrarenal ${ }^{a}$} \\
\hline CSF-1 & $3 \pm 2$ & $6 \pm 3$ & $15 \pm 2^{b}$ & $14 \pm 4^{b}$ \\
\hline GM-CSF & $12 \pm 4^{b}$ & $16 \pm 4^{b}$ & $40 \pm 6^{b, c}$ & $53 \pm 13^{b, c}$ \\
\hline Uninf. & $0 \pm 0$ & $0 \pm 0$ & $2 \pm 1$ & $2 \pm 2$ \\
\hline $\begin{array}{l}{ }^{a} \text { Subcapsular } \\
\text { lesion. Recipi } \\
\text { Uninf., retrov } \\
{ }^{b} p<0.05 \text { ver } \\
{ }^{c} p<0.05 \text { ver }\end{array}$ & $\begin{array}{l}\text { ll infiltratic } \\
\text { mice, } 10- \\
\text { EC. }\end{array}$ & $\begin{array}{l}\text { by countin } \\
n=3 \text { in }\end{array}$ & $\begin{array}{l}\text { cell layers in } \\
\text { oer of implan }\end{array}$ & $\begin{array}{l}\text { greatest } \\
\text { mouse. }\end{array}$ \\
\hline
\end{tabular}



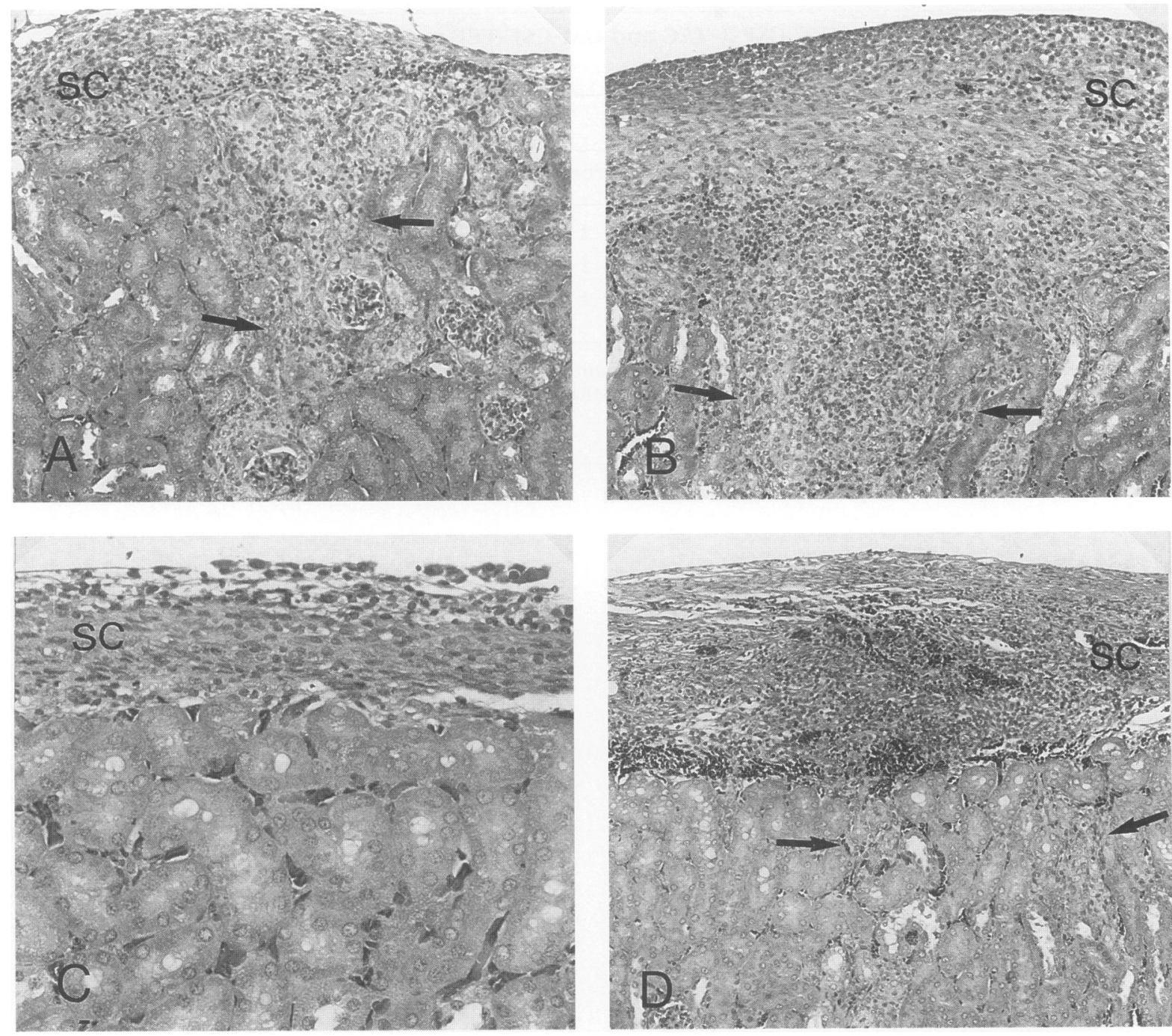

FIG. 4. Intrarenal lesions induced by GM-CSF are more rapid than CSF-1 in MRL-lpr mice

GM-CSF caused a substantial accumulation of cells extending from the subcapsule into the cortex in MRL-lpr kidneys by 8 days post-Ix (A, arrows), and more extensively by 15 days (B, arrows). In contrast, CSF- 1 did not cause an accumulation of cells at 8 days (C), and the numbers of cells accumulated in the renal cortex, although evident by 15 days (D, arrows), were not as great as for GM-CSF. sc, subcapsular space. (Hematoxylin and eosin; magnification: A, B, and D, 300×; C, 500×.)

TEC did not promote an accumulation of cells 90 days post-Ix.

\section{Effect of Age}

We implanted $1 \times 10^{6}$ CSF-1-TEC or GM-CSFTEC into MRL-lpr recipient mice of different ages; $4,6-8,10-12$, and 20 weeks, and compared the renal pathology in each group 28 days post-Ix. The MRL-lpr kidney is normal at 4 weeks of age; overt renal injury first appears 8 weeks, and is readily detectable by 20 weeks of age (2). CSF-1-TEC did not cause cells to accu- mulate in 4 weeks old MRL-lpr mice. However, CSF-1 initiated a similar amount of renal injury in MRL-lpr mice at 6-8, 10-12, and 20 weeks of age (Table 7). In contrast, GM-CSF-TEC induced renal injury in all age groups (4-20 weeks), and the extent of the lesion was always more severe than CSF-1-TEC.

\section{CSF-1-TEC Remain in the Implant Site}

$\beta$-gal-CSF-1-TEC ("co-infected" TEC) implanted under the renal capsule were detected by the presence of $\beta$-gal. These cells were confined to 
TABLE 7. To induce cell infiltration with CSF-1, recipient MRL-lpr mice need to be at least 6 weeks of age

\begin{tabular}{|c|c|c|c|c|}
\hline \multirow[b]{2}{*}{ TEC } & \multicolumn{4}{|c|}{ Age } \\
\hline & 4 Weeks & $\begin{array}{c}\text { 6-8 } \\
\text { Weeks }\end{array}$ & $\begin{array}{c}10-12 \\
\text { Weeks }\end{array}$ & 20 Weeks \\
\hline \multicolumn{5}{|c|}{ A. Subcapsular } \\
\hline CSF-1 & $18 \pm 2$ & $37 \pm 6^{b}$ & $29 \pm 3^{b}$ & $25 \pm 3^{b}$ \\
\hline $\begin{array}{l}\text { GM- } \\
\text { CSF }\end{array}$ & $44 \pm 5^{b, c}$ & $57 \pm 8^{b, c}$ & $68 \pm 13^{b, c}$ & $49 \pm 6^{b, c}$ \\
\hline Uninf. & $15 \pm 4$ & $12 \pm 2$ & $14 \pm 2$ & $12 \pm 1$ \\
\hline \multicolumn{5}{|c|}{ B. Intrarenal ${ }^{a}$} \\
\hline CSF-1 & $2 \pm 2$ & $17 \pm 4^{b}$ & $14 \pm 4^{b}$ & $15 \pm 3^{b}$ \\
\hline $\begin{array}{l}\text { GM- } \\
\text { CSF }\end{array}$ & $37 \pm 16^{b, c}$ & $39 \pm 6^{b, c}$ & $53 \pm 13^{b, c}$ & $37 \pm 11^{b, c}$ \\
\hline Uninf. & $2 \pm 2$ & $1 \pm 1$ & $2 \pm 2$ & $2 \pm 2$ \\
\hline \multicolumn{5}{|c|}{$\begin{array}{l}{ }^{a} \text { Subcapsular and intrarenal cell infiltration was evaluated by counting the numbers of cell layers in an area with the greatest } \\
\text { lesion. Histological evaluation: } 28 \text { days post-Ix. Recipients were MRL-lpr mice. } n=3 \text { in each group. Number of implanted cells: } \\
1 \times 10^{6} / \text { mouse. Uninf., retroviral uninfected TEC. }\end{array}$} \\
\hline
\end{tabular}

TABLE 8. CSF-1 induces an initial accumulation of $M \phi$ (3-7 days), followed by lymphocytes (14-28 days) in the MRL-lpr kidney

\begin{tabular}{|c|c|c|c|c|c|}
\hline \multirow[b]{2}{*}{ Cell } & \multirow[b]{2}{*}{$\%$} & \multicolumn{4}{|c|}{ Post-Ix } \\
\hline & & 3 Days & 7 Days & 14 Days & 28 Days \\
\hline \multicolumn{6}{|l|}{ A. Subcapsular } \\
\hline IX-TEC & $\beta$-gal & 30 & 20 & 10 & 5 \\
\hline M $\phi$ & $\mathrm{F} 4 / 80$ & 60 & 50 & 20 & 10 \\
\hline \multirow[t]{3}{*}{ Lymphocytes } & B220 & $<5$ & 20 & 30 & 40 \\
\hline & $\mathrm{CD} 4$ & $<5$ & 5 & 30 & 40 \\
\hline & CD8 & 0 & 5 & $<5$ & $<5$ \\
\hline \multicolumn{6}{|l|}{ B. Intrarenal } \\
\hline $\mathbf{M} \phi$ & $\mathrm{F} 4 / 80$ & - & 70 & 50 & 10 \\
\hline \multirow[t]{3}{*}{ Lymphocytes } & B220 & - & 10 & 20 & 40 \\
\hline & CD4 & - & 10 & 20 & 40 \\
\hline & CD8 & - & 10 & $<5$ & $<5$ \\
\hline
\end{tabular}

Recipients were MRL-lpr mice, 10-12 weeks of age, $n=3$ in each age group. Number of implanted cells: $1 \times 10^{6} /$ mouse. Cell phenotypes in subcapsular and intrarenal lesions were determined by counting cells with $\beta$-galactosidase ( $\beta$-gal) activity and cells expressing F4/80, B220, CD4, or CD8. Ix, implantation. 

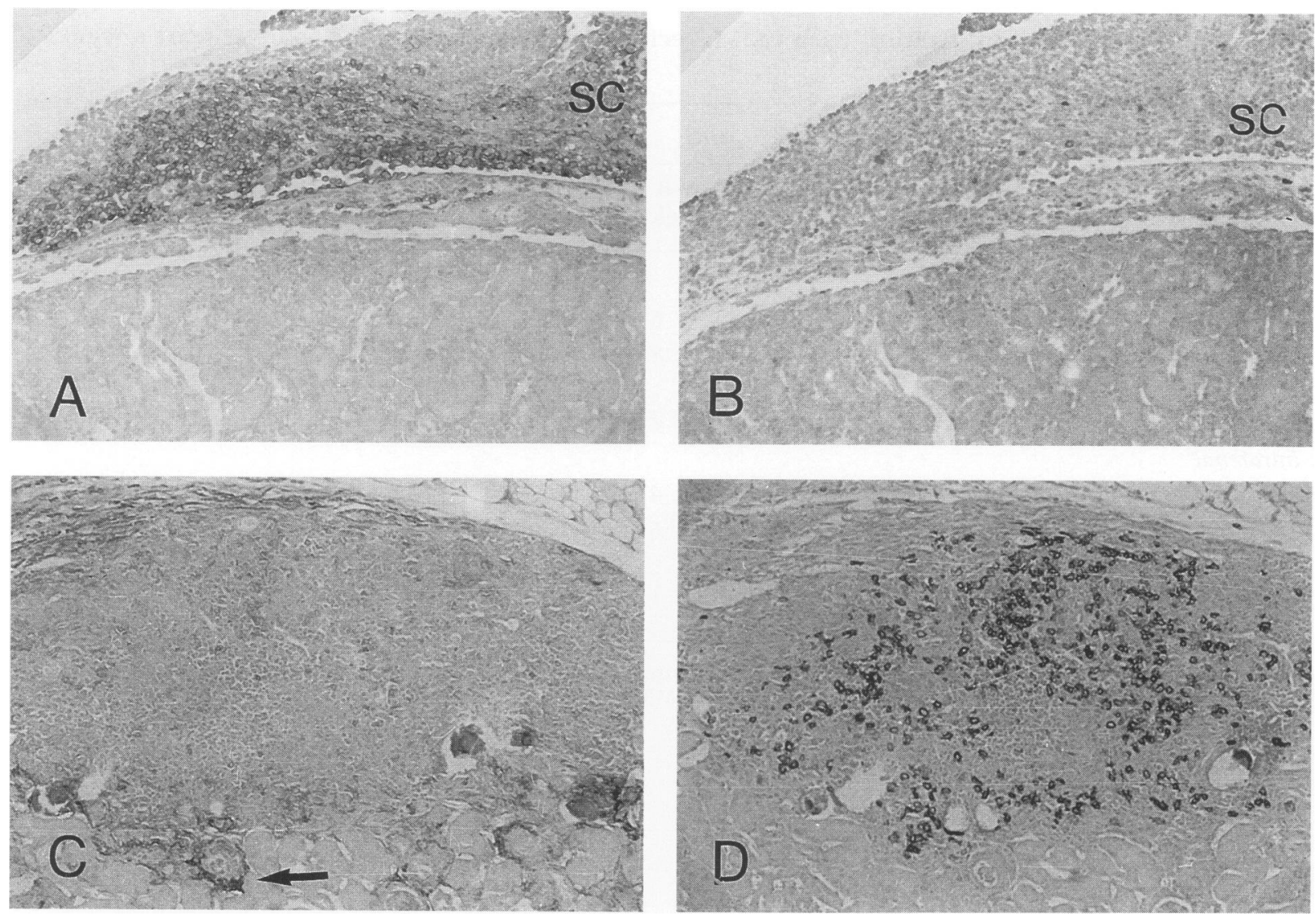

FIG. 5. Local overexpression of CSF-1 causes initial $M \phi$ accumulation, followed by lymphocytes infiltration in the MRL-lpr kidney

Three days post-Ix, the cells accumulated in the capsule are predominantly $M \phi(F 4 / 80)(A)$, with only a few lymphocytes (B). By comparison, 28 days post-Ix, only a few $M \phi$ were identified in the intrarenal lesion (C, arrow) in which many B220-positive cells accumulated (D). sc, subcapsular space. (Magnification: A-D, 330×.)

the subcapsular space, and did not migrate into the renal cortex (Fig. $2 \mathrm{~F}$ and $\mathrm{G}$ ). $\beta$-gal could be detected in $30-40 \%$ of the cells in the subcapsular space 3 days post-Ix; the proportion decreased to $<10 \%$ by 28 days post-Ix (Table $8 \mathrm{~A}$ ).

\section{$M \phi$ Growth Factors Incite an Accumulation of $M \phi$ Followed by Lymphocytes}

CSF-1-TEC and GM-CSF-TEC induced an accumulation of primarily $M \phi$ (3-7 days) which became predominantly lymphocytes (14-28 days post-Ix) in the MRL-lpr kidney. Few granulocytes were identified between 3 and 28 days; even at 1 day post-Ix of GM-CSF-TEC, we were unable to find many granulocytes. At 3 and 7 days post-Ix, the cells accumulating in the subcapsular space were predominantly $M \phi(>50 \%$;
Fig. 5 and Table 8). Lymphocytes, including $\mathrm{B}^{2} 20^{+}$cells and $\mathrm{CD} 4^{+}$T cells, appeared by 7 days post-Ix and increased in the subcapsule and within the kidney. At 28 days post-Ix, the majority $(80 \%)$ of the infiltrating cells expressed CD4, CD8, or B220, and only a few $\mathrm{M} \phi(10 \%)$ were detected (Fig. 5 and Table 8). By 90 days post-Ix, morphologically most cells were lymphocytes; approximately $20 \%$ were plasma cells, and the remainder were $M \phi$ and dendritic cells. The ratio of $M \phi$ and lymphocytes in the subcapsular and intrarenal lesions induced by GM-CSF was similar to CSF-1 at each time point. In $\mathrm{C} 3 \mathrm{H}-$ lpr recipients, the phenotypes of the cells accumulating under the renal capsule and within the kidney were similar to those in MRL-lpr mice 28 days post-Ix. In contrast, in $\mathrm{C} 3 \mathrm{H}-++$ and MRL- + + recipients few $M \phi$ were detected at any time point and lymphocytes were absent. 


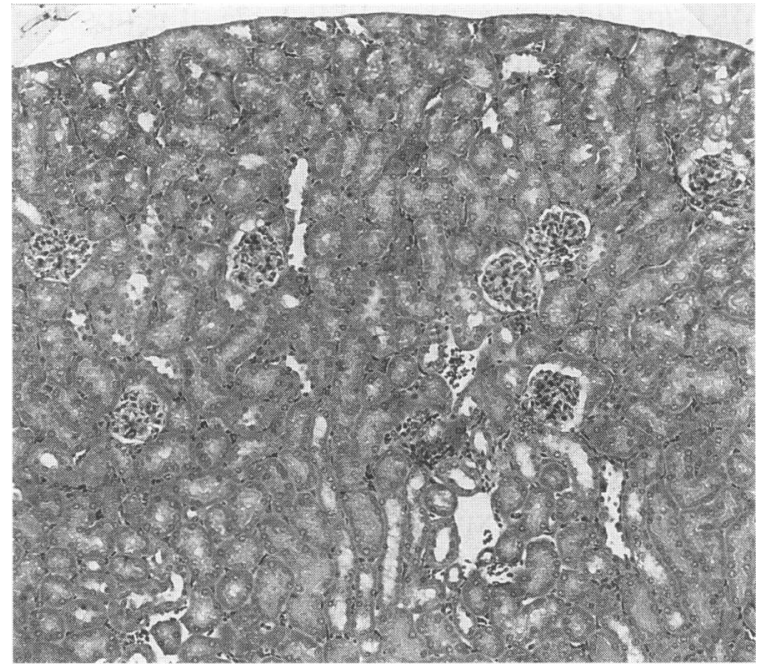

FIG. 6. CSF-1 overexpression in the circulation does not accelerate renal pathology

CSF-1-TEC in the left MRL-lpr kidney caused sustained, high levels of CSF-1 expression in the systemic circulation, but did not induce any change in glomeruli, interstitium, and perivascular areas in the contralateral (right) kidney. Twenty-eight days postIx. (Hematoxylin and eosin; magnification: 200×.)

\section{Circulating CSF-1 or GM-CSF Does Not Exacerbate Renal Pathology in MRL-lpr Mice}

We implanted CSF-1-TEC into the left kidney of MRL-lpr recipients and examined the contralateral (right) kidney 28 days post-Ix. In spite of high levels of serum CSF-1 for at least 4 weeks post-Ix (Table 3), there was no detectable increase in the numbers of cells in the glomeruli, interstitium, or perivascular lesions in the contralateral kidney as compared with untreated age-matched MRL-lpr kidneys (Fig. 6). Similarly, circulating GM-CSF did not alter renal pathology.

\section{DISCUSSION}

We tested the hypothesis that locally produced CSF-1 attracts and fosters the accumulation of $M \phi$ in the kidney, and in turn induces renal injury. To accomplish this goal, we used an ex vivo gene transfer strategy. We genetically modified cells that are intrinsic to the kidney, and showed that they produced stable levels of CSF-1. The MoMuLV recombinant retrovirus vector is efficient in a wide variety of mammalian cells (20), and we found that infection of renal
TEC with this vector was $90 \%$ efficient. These genetically modified TEC retained their ability to secrete high levels of cytokine for at least 1 year. The genetically modified TEC were placed under the renal capsule, a site that proved ideal for delivering CSF-1 and GM-CSF into the kidney and circulation. This in part, related to the rapid and extensive neovascularization of the subcapsular implant $(21,22)$.

The introduction of either CSF-1-TEC or GM-CSF-TEC caused renal injury in mice with the $l p r$ mutation, but not in normal strains. Of note, introduction of CSF-1 into the kidney of $\mathrm{C} 3 \mathrm{H}-\mathrm{lpr}$ mice, which do not normally express renal CSF-1 or develop renal disease, induces tissue damage. These $M \phi$ growth factors initiated a greater amount of renal injury in mice with the MRL background than mice with $\mathrm{C} 3 \mathrm{H}$ background. We view $M \phi$ growth factors as the "match" and the lpr mutation and strain background the "tinder", which when combined incite renal destruction.

The $l p r$ mutation affects the gene encoding the Fas antigen (4). The abnormal Fas protein may be responsible for the animal's inability to delete autoreactive cells in the periphery by programmed cell death (apoptosis). The mutation may be partially responsible for the increase in $\mathrm{T}$ cells in the kidney of MRL-lpr mice $(23,24)$. Since other mice with the $l p r$ mutation such as C3H-lpr, do not have nephritis, the MRL background contributes to the mechanism of renal injury. Numerous cytokine changes are related to the lpr mutation (TNF, IL-6), the MRL background (IL-1, TNF) or both (25-27). Our studies show that even in the presence of the lpr mutation, the background strain determines the severity of renal injury induced by subcapsular genetically modified TEC.

Local production within the kidney, and not systemic exposure to $M \phi$ growth factors, incites renal injury. The extent of kidney damage is most severe nearest the source of CSF-1 or GMCSF. However, we do not know whether high serum levels in combination with local production augments tissue destruction since we cannot deliver $\mathbf{M} \phi$ growth factors into the kidney without also elevating systemic levels. Local delivery of $M \phi$ growth factor causes a high sustained level within the tissue which is impossible to achieve systemically. In addition, $M \phi$ growth factors released in the kidney may be trapped and facilitate the binding of CSF-1 or GM-CSF to their respective receptors (28). No doubt we could suggest numerous plausible explanations to ac- 
count for the necessity of local production within the kidney to incite tissue injury. It is of interest that elevated systemic levels of CSF-1 or GMCSF alone did not incite tissue injury. Systemic delivery of $M \phi$ growth factors is given to accelerate the repopulation of progenitor cells in chemotherapy patients with white cell deficiencies (29). Our studies would suggest that these therapeutic systemic doses would not promote kidney injury, even in patients with an autoimmune propensity.

GM-CSF incites renal injury substantially more rapidly than CSF-1, perhaps because GMCSF is a growth factor for granulocytes and $M \phi$. However, we did not detect more than an occasional granulocyte in any of the kidneys in which implantation of GM-CSF-TEC initiated renal injury. Thus, it is unlikely that granulocytes were responsible for increasing renal injury. However, it is possible that GM-CSF is more potent than CSF- 1 as a chemoattractant and in inducing proliferation of $M \phi$. In fact, we have determined that GM-CSF causes bone marrow $\mathrm{M} \phi$ from MRL mice to proliferate 3-fold more than CSF-1. Similarly, GM-CSF causes $M \phi$ in lungs to proliferate more than CSF-1 (30). Another possible explanation for the more rapid induction of renal injury by GM-CSF may be related to the ability of GM-CSF to induce costimulatory molecules such as B7. Expression of B7 along with MHC Ia would promote $\mathrm{T}$ cell activation (31). We are currently investigating these differing biologic functions so that we can identify the reason for the far more rapid impact of GM-CSF compared with CSF-1 in inciting renal destruction.

Renal damage in the tissue adjacent to the implant site remains evident several months after introduction of M $\phi$ growth factors. CSF- 1 and GM-CSF are produced by TEC for more than several weeks; although levels in the circulation diminish, these genetically modified TEC might continue to secrete cytokine. Although GM-CSF incites a more rapid accumulation of cells than CSF-1, the extent of renal injury by 90 days post-Ix is similar. It is possible that spontaneous autoimmune reactions in MRL-lpr recipients influence the renal injury after several months. At that time, progression of pathology might no longer result from CSF-1-TEC or GM-CSF-TEC secreting cytokines. The cellular composition in these later lesions is predominantly lymphocytes, but there are many plasma cells and some $M \phi$, similar to the perivascular infiltrates in untreated MRL-lpr mice. Since vascular endothelial cells in
MRL-lpr kidneys express CSF-1 (2), it is possible that CSF-1 induces the lesions.

The finding that CSF-1 and GM-CSF incites more severe renal lesions in MRL-lpr than by $\mathrm{C} 3 \mathrm{H}-l p r$ mice, and that MRL-lpr mice must be at least 6 weeks of age for CSF-1 to initiate an accumulation of $M \phi$ and $\mathrm{T}$ cells may relate to expression of CSF-1 and TNF- $\alpha$ in the kidney of MRL-lpr, but not C3H-lpr mice $(2,25)$. $M \phi$, derived from MRL-lpr but not $\mathrm{C} 3 \mathrm{H}-l p r$, exposed to TNF- $\alpha$ along with CSF-1 proliferate more compared with CSF-1 alone (32). Since MRL-lpr mice may also express numerous unidentified molecules, we plan to determine which molecules are newly expressed in MRL-lpr between 4 and 6 weeks of age and absent in $\mathrm{C} 3 \mathrm{H}-\mathrm{lpr}$ kidneys.

In summary, we have established a novel gene transfer system to deliver cytokines specifically into the kidney. This approach is particularly valuable for identifying the impact of local as well as systemic overexpression of molecules on the kidney. Since CSF-1, TNF- $\alpha$, and IL- 6 are increased within the kidney and circulation in MRL-lpr mice, we have constructed a strategy to establish which of these cytokines are instrumental in initiating renal injury. We now report that CSF-1 expressed in the kidney of MRL-lpr mice initiates renal injury. In addition, we have recently established that IL-6 (manuscript submitted) and TNF $\alpha$ (manuscript in preparation) alone do not incite renal injury in mice with the $l p r$ mutation. Thus, these studies offer a strategy to explore the impact of local and systemic cytokine production on renal injury.

\section{ACKNOWLEDGMENTS}

This work was supported by National Institutes of Health, DK-36149 (VRK), and the Baxter Extramural Grant Program (VRK). We wish to thank Dr. Robert Schwartz for his editorial review and suggestions.

\section{REFERENCES}

1. Schreiner GF. (1991) The role of the macrophage in glomerular injury. Semin. Nephrol. 11: $268-275$.

2. Bloom RD, Florquin S, Kelley VR. (1993) Colony stimulating factor-1 in the induction of lupus nephritis. Kidney Int. 43: 1000-1009.

3. Theophilopoulos AN, Dixon FJ. (1985) Mu- 
rine models of systemic lupus erythematosus. Adv. Immunol. 37: 269-390.

4. Watanabe-Fukunaga R, Brannan CI, Nagata S. (1992) Lymphoproliferation disorder in mice explained by defects in Fas antigen that mediates apoptosis. Nature 356: 314-317.

5. Wang JM, Griffin JD, Mantovani A. (1988) Induction of monocyte migration by recombinant macrophage colony-stimulating factor. J. Immunol. 141: 575-579.

6. Metcalf D. (1985) The granulocyte-macrophage colony-stimulating factors. Science 229: 16-22.

7. Yui MA, Brissette WH, Rubin-Kelley VE. (1991) Increased macrophage colony-stimulating factor in neonatal and adult autoimmune MRL-lpr mice. Am. J. Pathol. 139: 255261.

8. Brennan DC, Jevnikar AM, Kelley VR. (1992) Cultured mesangial cells from autoimmune MRL-lpr mice have decreased secreted and surface M-CSF. Kidney Int. 42: 279-284.

9. Naito T, Griffiths RC, Kelley VR. (in press) Transplant approach establishes: Kidneys are responsible for serum CSF-1, but requires a stimulus in MRL-lpr mice. Kidney Int.

10. Bosch R, Woolf AS, Fine LG. (1993) Gene transfer into mammalian kidney: Direct retrovirus-transduction of regenerating tubular epithelial cells. Exp. Nephrol. 1: 49-54.

11. Isaka Y, Fujiwara Y, Imai E. (1993) Glomerulosclerosis induced by in vivo transfection of transforming growth factor- $\beta$ or plateletderived growth factor gene into the rat kidney. J. Clin. Invest. 92: 2597-2601.

12. Kitamura M, Tayler S, Fine LG. (1994) Gene transfer into the rat renal glomerulus via a mesangial cell vector: site-specific delivery, in situ amplification, and sustained expression of an exogenous gene in vivo. J. Clin. Invest. 94: 497-505.

13. Moullier P, Friedlander G, Ferry N. (1994) Adenoviral-mediated gene transfer to renal tubular cells in vivo. Kidney Int. 45: 12201225.

14. Wuthrich RP, Glimcher LH, Kelley VE. (1990) MHC class II, antigen presentation and tumor necrosis factor in renal tubular epithelial cells. Kidney Int. 37: 783-792.

15. Danos O, Mulligan RC. (1988) Safe and efficient generation of recombinant retroviruses with amphotropic and ecotropic host ranges. Proc. Natl. Acad. Sci. U.S.A. 85: 64606464.
16. Wilson JM, Jefferson DM, Mulligan RC. (1988) Retrovirus-mediated transduction of adult hepatocytes. Proc. Natl. Acad. Sci. U.S.A. 85: 3014-3018.

17. Dranoff G, Jaffee E, Mulligan RC. (1993) Vaccination with irradiated tumor cells engineered to secrete murine granulocytemacrophage colony-stimulating factor stimulates potent, specific, and long-lasting antitumor immunity. Proc. Natl. Acad. Sci. U.S.A. 90: 3539-3543.

18. Dannenberg AM, Suga M. (1981) Histochemical stains for macrophages. In: Adams DO, Edelson PJ, Koren MS (eds). Methods for Studying Mononuclear Phagocytes. Academic Press, New York, pp. 375-396.

19. Bradley TR, Metcalf D. (1966) The growth of mouse bone marrow cells in vitro. Aust. J. Exp. Biol. Med. 44: 287-299.

20. Mulligan RC. (1991) Gene transfer and gene therapy. Principles, prospects, and perspective. In: Lindsten J, Petterson U (eds). Etiology of Human Diseases at the DNA Level. Raven Press, New York, pp. 143-189.

21. Hayek A, Culler FL, Baird A. (1987) An in vivo model for study of the angiogenetic effects of basic fibroblast growth factor. Biochem. Biophys. Res. Commun. 147: 876-880.

22. Mendola JF, Goity C, Gomis R. (1994) Immunocytochemical study of pancreatic islet revascularization in islet isograft. Transplantation 57: 725-730.

23. Gallo CD, Jevnikar AM, Kelley VR. (1992) Autoreactive kidney-infiltrating T-cell clones in murine lupus nephritis. Kidney Int. 42: 851-859.

24. Singer GG, Abbas AK. (1994) The Fas antigen is involved in peripheral but not thymic deletion of $\mathrm{T}$ lymphocytes in $\mathrm{T}$ cell receptor transgenic mice. Immunity 1: 365-371.

25. Yokoyama H, Kreft B, Kelley VR. (1995) Biphasic increase in circulating and renal TNF- $\alpha$ in MRL-lpr mice with differing regulatory mechanisms. Kidney Int. 47: 122-130.

26. Tang B, Matsuda T, Kishimoto T. (1991) Age-associated increase in interleukin 6 in MRL/lpr mice. Int. Immunol. 3: 273-278.

27. Boswell JM, Yui MA, Kelley VE. (1988) Increased tumor necrosis factor and IL- $1 \beta$ gene expression in the kidneys of mice with lupus nephritis. J. Immunol. 141: 3050-3054.

28. Stein J, Borzillo GV, Rettenmier CW. (1990) Direct stimulation of cells expressing receptors for macrophage colony-stimulating factor (CSF-1) by a plasma membrane-bound 
precursor of human CSF-1. Blood 76: 13081314.

29. Steward WP, Scarffe JH, Crowther D. (1989) Recombinant human granulocyte macrophage colony stimulating factor (rhGM-CSF) given as daily short infusions-A phase I dose-toxicity study. Br. J. Cancer 59: 142145.

30. Chen BDM, Mueller M, Chou TH. (1988) Role of granulocyte/macrophage colonystimulating factor in the regulation of mu-

Contributed by R. Cotran on February 22, 1996. rine alveolar macrophage proliferation and differentiation. J. Immunol. 141: 139-144.

31. Larsen CP, Shannon CR, Pearson TC. (1994) Regulation of immunostimulatory function and costimulatory molecule (B7-1 and B7-2) expression on murine dendritic cells. $J$. Immunol. 152: 5208-5219.

32. Moore KJ, Yeh $\mathrm{K}$, Naito $\mathrm{T}$, Rubin Kelley V. (1996) TNF $\alpha$ enhances CSF-1 induced macrophage accumulation in autoimmune renal disease. J. Immunol. (In press). 